\title{
THE DYNAMIC VIEWS OF KIAIS IN RESPONSE TO THE GOVERNMENT REGULATIONS FOR THE DEVELOPMENT OF PESANTREN
}

\author{
Moh. Asror Yusuf \\ State Institute of Islamic Studies (IAIN) Kediri \\ asroryusuf@iainkediri.ac.id \\ Ahmad Taufiq \\ State Institute of Islamic Studies (IAIN) Kediri \\ taufiqahmad34@yahoo.co.id
}

\begin{abstract}
The study discusses the dynamics of kiais' views in response to the government regulations to develop education in pesantren. It is a descriptive qualitative study on the kiais in Pondok Pesantren Lirboyo, Kediri, East Java, Indonesia. Using a theory of social construction of reality, it scrutinizes the regulations that the government issued and the ways the kiais are responding to them. The social construction of the kiais brings a dynamic action in developing the pesantren. Government regulations related to the education in pesantren, as a social reality, are not textually accepted. Rather, the kiais always seek to address these regulations creatively and dynamically as to integrate the education in pesantren with the old tradition and modernity, because of which the needs and development of society can be fulfilled. The knowledge of the kiais influences the actions in developing education in pesantren. Innovative and dynamic views of the kiais lead to the growth of pesantren in multiple dimensions.
\end{abstract}

Keywords: Kiai, pesantren, social construction, regulations on pesantren. 


\section{A. Introduction}

The development of education in pesantren cannot be totally separated from government regulations. Changes in these regulations always affect the dynamics of education in pesantren and other Islamic educational institutions (Muhajir, 2010; Zuhri, 2006). The relations between pesantren (Islamic Boarding School) and the government, historically, had experienced ups and downs in some different eras (Suparta, 2014). During the Dutch colonial rule, it was under high pressures and marginalization (OECD/ADB, 2015). The movement of Indonesian Muslims to perform the hajj has been restricted, resulting to the limited number of Muslims who understood, appreciated, and practiced the teachings of Islam. Thus, the development of Islamic education was very slow (Burhanudin, 2004; Dhofier, 1985). These limitations were carried out through, some of them, the resolutions of 1825 and 1831, as well as the ordinance of 1859 (Goksoy, 2002). The three regulations aimed to control the hajj that the government considered a threat to the power of the government colonies along the Dutch East Indies (Burhanudin, 2012).

Despite of the high pressure from the colonial government, pesantren did not stop to grow. Even the policy made the kiais transform into active communities as opposed to the Islamic officials (penghulu), the religious elite, who received support from the Netherlands at the time. The kiai (the pesantren leader) had dynamically developed and consciously demonstrated an attitude of social and religious types of pesantren. By doing so, pesantren was growing, especially in quantity. The number of pesantren and other 
Islamic educational institutions, such as surau and dayah, was proliferating. The network with the Middle East went more intensive that Mecca became a center for the development of pesantren (Burhanudin, 2012). The educational model of pesantren in Indonesia today is even adopted by some favorite Islamic schools with fine quality, such as the Islamic School of Al-Azhar, the Islamic School of Madania, SMU Islam Cendekia which in the end turns into MAN Insan Cendekia. These schools are implementing the boarding school system of pesantren (Azra, 2015).

The end of the colonial governance did not mean a better treatment for pesantren. Marginalization continued but did not stop this institution to move forward dynamically in order to meet the needs of society. During the condition, kiais, as caregivers, played a crucial role (Dhofier, 1985) because they were the essential element of pesantren (Lukens-Bull, 2004).

Meanwhile, the growth of pesantren depended on the personal ability of the kiai (Dhofier, 1985; Raihani, 2012). The development and modernization had been going on since the beginning of the 20th century. Tebuireng, Jombang East Java, was the first pesantren which went into modernization and education innovation (Suharto, 2014). This development, due to the impact of the ethical politics of the Dutch colonialism (Burhanudin, 2004; Yamaguchi, 2016) and the Islamic reformism (Burhanudin, 2012), did not weaken kiais although they had to share their authority with teachers or other educators (Arifin, 2013). Society still recognized them as the central figures in pesantren. Within the political practice, for example, the authority of kiai should have been weakened, but they still had a vital role (Turmudzi, 2006). This influential 
role let the kiais decide and direct the development and the future of pesantren (Dhofier, 1985). Independence, as one of the crucial aspects of kiais (Turmudzi, 2006) can result in different policies (Frederick \& Worden, 2011). Their creativities are diverse, indicated by the presence of various dimensions in the educational development of pesantren (Dhofier, 2011).

The kiais in Indonesian pesantren have been out of the control of the government bureaucracy. Unlike the system that the British carried out in Malaysia, the Dutch allowed Islamic education or pesantren to go outside the control of the local aristocrats and the emerging state bureaucrats (Sidel, 2001). In Malaysia, religious leaders are not as free as those in Indonesia. In the last few decades, it appeared that they were not allowed to deviate from the line or rule of the government. In general, this is different from kiais of pesantren in Indonesia, who are relatively independent and free from the government (Shiozaki \& Kushimoto, 2014). They are independent in making decisions and actions.

The dynamic character of kiais and pesantrens has been an exciting topic for a lot of researchers from various disciplines. Some studies on the dynamic character of kiai are Clifford Geertz, The Javanese Kijaji: The Changing Role of a Cultural Broker (1960); Zamakhsyari Dhofier, The Pesantren Tradition: The Role of The Kyai in The Maintenance of Traditional Islam in Java (1980); Hiroko Horikoshi, Kyai dan Perubahan Sosial (1987); Iik Arifin Mansurnoor, Ulama Vilagers and Change Islam in Centeral Madura (1987); Pradjarta Dirdjosanjoto, Memelihara Umat: Kyai Pesantren Kyai Langgar (1999); Ronald Alan Lukens-Bull, Jihad ala 
Pesantren di Mata Antropolog Amerika (2004); Abdurrahman Mas'ud, Dari Haramain Ke Nusantara: Jejak Intelektual Arsitek Pesantren (2006); Endang Turmudi, Struggling For The Umma: Changing Leadership Roles of Kyai in Jombang East Java (2006); Jajat Burhanudin, Ulama dan Kekuasaan: Pergumulan Elite Muslim dalam Sejarah Indonesia (2012).

The various studies above discussed the mechanism how kiais are dealing with two interrelated things, i.e. preserving the old tradition and negotiating modernity. Firstly, they build a network of intellectual and spiritual relationships. Secondly, they modernize education in pesantren (Raihani, 2012) and engage in politics. They performed this mechanism with different emphasis (Fauzi, 2012).

The government had issued many regulations and policies related to education in pesantren since the days of colonial period up to now (Suparta, 2014). The government recognized pesantren as a part of the national education system, especially after the issuance of Law Number 20, 2003, in particular, Article 30 (4), 2003, which grants more freedom to the kiais in developing education in pesantren. The government has also published various regulations and their derivatives, including PP. Number 55, 2007, PMA Number 13, 2014, PMA Number 18 2014, and the PMA Number 71, 2015, which is an indication that it gains more considerable attention. These regulations strengthen the existing recognition of society on pesantren, especially after the termination of the New Order government. The recognition brings more burden and responsibility to pesantren. As caregivers, the kiais are required to be creative that pesantren can develop and meet the needs and dynamics of society. 
The wide range of regulation and policy gives the kiais flexibility and autonomous action, which is always moving and changing according to different conditions. The kiais always create various policies. The kiais tend to have diverse views which are, nevertheless, based on the principle of moderation and nonextremism (Yusuf, 2010), as it is apparent from the religious curriculum being developed in some pesantrens (Basri, 2014; Zulkarnain, 2015). Different views of the kiais do not only depend on the different pesantrens, but also the different periodic leadership of the same pesantren, said Wahid in his foreword to Dirdjosanjoto's Memelihara Umat: Kyai Pesantren Kyai Langgar (Dirdjosanjoto, 1999).

The above description signifies the importance of studies on the dialectic between the kiais and the government policy in order to understand their autonomy and creativity in addressing the policy. The current study examines the dynamic views of kiais in response to the government regulation in the development of education in pesantren. It is a descriptive qualitative study. The analysis is built on the theory of social construction of reality, which is missing in the previous studies. The object of the study is the kiais in Pesantren Lirboyo, Kediri, East Java, Indonesia.

\section{B. The Social Construction of Kiais upon Social Reality}

The dynamic actions of kiais are interrelated with the social construction that they develop. The knowledge of kiais is always dialectically related to social realities. Peter L. Berger, known for his theory of social construction of reality, explains that the dialectic between knowledge and social reality is the source of social change. The overall thoughts of Berger about 
social change cannot be separated from two main concepts in the sociology of knowledge, which are "knowledge" and "reality" (Berger \& Luckmann, 1966). It shows that there is connection between knowledge as a subjective reality and reality as an objective fact. On the one hand, objective reality is highly dependent on human knowledge. On the other hand, human knowledge is highly contingent on the objective reality. Berger describes the first as "society in man" and the second as "man in society" (Berger, 1963).

Berger then explained both concepts in his book coauthored with Thomas Luckmann, The Social Construction of Reality: a Treatise in the Sociology of Knowledge. He used in the book the terms "society as an objective reality" and "society as a subjective reality." Through both terms, Berger attempted to explain that-in contrast with the philosophers who search for the roots of knowledge and social reality and with the laypeople who take for granted whatever happens, social scientists will always look for the relationship between the social conditions and knowledge and social reality. Therefore, knowledge and reality are always relative, depending on the surrounding social context (Berger \& Luckmann, 1966). In addition, the very fact depends on the construction given by the society. Likewise, social construction cannot be separated from the surrounding social reality. Society is both an "objective reality" and a "subjective reality."

A reciprocal relationship between subjective knowledge and objective reality, according to Berger, is based on three main concepts: 1) the reality of everyday life; 2) social interaction in everyday life; and 3) language and knowledge in everyday life. The reality of the everyday life of human 
being becomes the center of attention for social scientists to explain the dynamics of social life. Human beings experience this reality not individually but together with others in social interaction. Besides, certain individuals also become a social reality for other individuals. From a wide range of interactions, the most important and the main concern to understand society is face-to-face interaction with one another. The result of these social interactions will be objectified into social reality through habituation, typification, and shared stock of knowledge (Samuel, 2012). The most crucial objectification is signification in which language is one of its elements. With language, objectification can be performed and maintained through legitimacy, and then internalized again by the individual as his or her subjective knowledge through socialization (Samuel, 2012).

Social interaction does not always produce a social reality on which the given different individuals share a common understanding. Socio-historical difference lets every individual adopt a different construction in understanding reality. The socio-historical background of every individual has an essential role in realizing both the objective social reality and the dynamic social change. Every individual goes through the life path in different processes and periods. As a result, social change will emerge. On the contrary, the same social change will also create a new socio-historical context that plays a vital role in determining the dynamics of social construction on the objective reality.

Knowledge (social construction) is always associated with its existence (i.e. personal and social context of the owner). Peter L. Berger is a sociologist who concerns with 
the importance of the use of sociology in understanding social reality and social change. He shows the significance of the sociology of knowledge especially being developed by Karl Mannheim. Mannheim is not the first who brings up this term, but he seeks to put the sociology of knowledge in the context of sociology (Baum, 1999). Max Scheler introduced the term "sociology of knowledge" in the 1920s in Germany. Initially, the term was part of a philosophical debate. Later on, Karl Manheim brought it into a sociological context, causing a continues and vigorous debate (pro and cons) about the sociology of knowledge (Berger \& Luckmann, 1966).

Mannheim claimed that Sociology of Knowledge is a branch of Sociology. As a theory, it analyzes the relation between knowledge and existence. As a socio-historical research, this branch attempts to explore the forms brought by the relation between knowledge and existence in the human intellectual development (Mannheim, 1954). Referring to Mannheim, Berger stated that sociology of knowledge needs to focus on the social construction of reality carried out by the knowledge of society (Berger \& Luckmann, 1966). Therefore, social change, as a social reality, can be well understood if the knowledge of society is always taken into account in a sociohistorical context.

There are three main moments, which are the central concept of Berger's thought, that show the process of social formation as an objective and a subjective reality and social change as well. They are internalization, externalization, and objectification (Suhartini, 2013). At first, Berger said, a human is born like a tabula rasa (blank paper). Through socialization, which is both primary and secondary, someone can absorb 
the social environment where he or she belongs. People experience the so-called internalization throughout their life. Since social interaction is a world that has been already interpreted as a result of externalization from different individuals, internalization will also make human knowledge dynamic as well. During internalization, every human will interpret the objective reality differently, which is then used as a subjective knowledge (Samuel, 2012).

In addition to absorbing dynamically a objective reality into a subjective knowledge, humans also perform externalization (a disclosure of subjectivity) through activities in order to survive (Samuel, 2012). Humans are the products of community and vice versa (Pramono, 2018). On the one hand, the ongoing externalization will produce a society as an objective reality (through habituation, typification, and shared stock of knowledge) and maintain it (through legitimacy). On the other hand, this process also will cause social change as it relates to the dynamics of socio-historical condition.

Every kiai in pesantren has a socio-historical condition, including background of life, social and cultural environment, experience, education, condition of the pesantren, insights in the study of religious books and other sciences, as well as social relationship. All these conditions grow dynamically and differently with one another, determining the dynamics of their knowledge on social reality. Thus, every kiai has a different social construction.

\section{The Government Regulations on Pesantren}

The development of education in pesantren is indispensable from government regulation. The policy of "ethical politics" introduced by Conrad Th. Van Deventer 
during the Dutch colonial government (Laffan, 2003), for example, had a very significant influence on the development of education in pesantren at the beginning of the 20th century. The introduction of a modern schooling model (Suparta, 2014) began to become effective since 1902 when W.F. Idenburg was the Minister of the colonial regime. J.H. Abendanon, who was appointed as the director of education in the Dutch East Indies in 1900-1905, preceded the same policy (Burhanudin, 2012). K.F. Holle and Snouck Hurgronje in the 19th century had an initiative to implant a modern mind and thought into the people of the Dutch East Indies (the natives). One of the impacts of this policy was the emergence of newly educated elites in the early 20 th century (Latif, 2005). In addition to the education for the aristocrats, the government also provided public schools for people and villagers since 1907 (Latif, 2005).

The policy, which might be also referred to as a politics of "association," was the amendment of the previous policy that has a severe impact on the people of the Dutch East Indies as well as limiting the freedom of the kiais in organizing religious education. It was enforced through a variety of rules in 1825, 1831, and 1859, aiming to restrict the pilgrims and to control their activities after returning from the hajj. The policy was based on the argument that the pilgrims had been involved in a number of uprisings against the colonial rule throughout the 19th century (Latif, 2005). These regulations slowed down the growth of muslims who understand, cherish, and practice the teachings of Islam (Dhofier, 1985).

The Dutch applied all these restrictions after successfully establishing its political power and economy, especially 
in Java, through the trading company called VOC, between 1677 and 1777. With the power and authority, this company distroyed the economy of the local people; as a consequence, the traders lost their jobs and turned into becoming farmers (Dhofier, 1985). The Dutch smashed the structure of social organization, economy, and the mentality of the local people as well (Furnivall, 2010).

Although the Dutch restricted their movements, the kiais and the hajj had more opportunities to develop the teachings of Islam through pesantrens established in rural areas. Likewise, when the policy of "ethical politics" was effectively enacted at the beginning of the 20th century, the kiais sought to develop their pesantrens by integrating tradition and modernity. It proves that the kiais always have dynamic attitudes and actions to preserve and develop the teachings of Islam in the changing society (Ubaidillah, 2014). The kiais do not interpret the government regulations as they are. They are always making a creative and dynamic move. Every kiai in a given period has a different attitude and action. An educational policy issued by the government may control the development of pesantrens. However, the kiais always find a way to respond the policy in a creative and dynamic manner.

The official recognition of pesantren as a part of the National Education System was declared for the first time through the Legislation of the Republic of Indonesia Number 20, 2003 on the National Education System. Chapter VI Article 13 states that religious education is one of the various types of education in Indonesia. Article 30, Paragraph 4, writes that pesantren is one of religious educations and it, therefore, deserves protection from the state (Tolchah, 
2014). A more detailed description of religious education is found in Government Regulation No. 55, 2007. In relation to pesantren, the Minister of Religious Affairs has published three Regulations, PMA No. 13, 2014 on the Religious Education of Islam, PMA No. 18, 2014 on the Education Unit of Muadalah (Equalization) in pesantren and PMA No. 71, 2015, on Ma'had Aly.

Thesevariousregulationshaveatleasttwo consequences. Firstly, the government pays a serious concern to pesantren (Azra, 2015).Secondly, the development of pesantren cannotbe separated from the government regulations. These regulations also further clarify the existence of pesantren among other types of Islamic educational institutions. Pesantren, along with Madrasah Diniyah (lit. Religious Schools), refers to the religious education of Islam, while madrasah and Islamic schools are parts of general education that is distinctively Islamic. Being recognized as equal as the public schools by the government, madrasah and Islamic schools should make a big adjustment to their curriculum with a 70 percent ratio for general science and 30 percent for Islamic sciences (Jabali \& Jamhari, 2003). This is in line with the stipulation mandated by the Joint Ministerial Decree (SKB) No. 6, 1975 (Basri, 2014; Suharto, 2013).

Out of the four types of education, pesantren has the most extensive coverage. The Government Regulation No. 55, 2007, Article 26 (2) mentioned, "pesantren may run Madrasah Diniyah or the integrated one with other education from pre-, elementary, secondary to higher education." The various types and levels of education in pesantren can be taking formal, non-formal, and informal forms. The fact that pesantren has 
its root in society renders a distinctively Indonesian flavor to pesantren, which is responsible for meeting the needs of the increasingly complex and remarkably changing society. Thus, it is reasonable if the policy of the Ministry of Religious affairs prioritizes this educational institution, as shown in the Decision of the Directorate General of Islamic Education Number 5877, 2014.

The regulations made since the issuance of Law No. 20, 2003 along with its various derivative rules imply the government's full recognition of the long-established pesantren. The government strongly believes that pesantren has the ability and the potential to engage fully in the development of the national education system. Pesantren, as an Islamic religious educational institution with a distinctively Indonesian educational character, possesses at least three potentials. First, pesantren has great potential to compete with the public education or with a more advanced one as developed in the Western countries. Second, it always strives as far as possible to produce graduates who also have expertise in religious knowledge (tafaqquh fi al-din). Third, the religious values of pesantren will make a human practice the teachings of Islam in a comprehensive way. The prospects of pesantren have pushed the government to issue regulations focusing two main aspects: 1) maintaining, preserving, and strengthening the tradition of pesantren; and 2) encouraging pesantren to update its institutional management, curriculum, and methods in alignment with the needs of the society.

The primary purposes of the implementation of pesantren education are to practice the teachings of Islam and to create Islamic experts (mutafaqqih fi al-din) who are 
socially and individually religious. The students in pesantren are expected to have a sincere, pure, independent, humble, tolerant, and moderate soul who can maintain and increase the spirits of fraternity with the fellow Muslims (PMA No. 13, 2014, Article 2). "In its implementation, pesantren can become a unit or the organizer of education" (PMA No. 13, 2014, Article 12). Pesantren can run both formal and nonformal Madrasah Diniyah, public schools, Islamic-based public schools, vocational schools, health school, Mu'adalah schools, higher education, and/or other educational programs (PMA No. 13 2014, Article 19).

The government, through the Ministry of Religious Affairs, legalizes the formal Madrasah Diniyah from elementary, intermediate, to higher levels (Ma'had Aly) (see the Decision of the Directorate General of Islamic Education Number 5839, 2014). Ma'had Aly, as a formal Madrasah Diniyah at the level of higher education has two objectives: 1) creating experts in the field of Islamic science; 2) developing yellow booksbased Islamic science (Regulation of the Ministry of Religious Affairs No. 71, 2015). In addition to the formal Madrasah Diniyah, pesantren may also manage Mu'adalah schools. The establishment of Mu'adalah schools has the same purpose to produce Islamic experts who can translate the teachings of Islam into practice. Similar to the formal Madrasah Diniyah and Ma'had Aly, the legalization of running Mua'adalah school comes from the Minister of Religious Affairs (Regulation of the Minister of Religious Affairs of the Republic of Indonesia Number 18, 2014). The graduates of the institutions are expected to master both religious and general knowledge. Therefore, the curriculum also includes the same materials 
as in the public schools. The curriculum in the Muadalah, Madrasah Diniyah, and Ma'had Aly must be integrated with that in the public schools (PMA 13 2014, Article 26. PMA 18, 2014, Article 10). Ma'had Aly, which seeks to produce graduates who can develop Islamic knowledge based on the yellow books (i.e. classical Islamic texts), should also develop a curriculum that will develop intelligence, noble characters, and skills (PMA 71, article 2, Article 11, Article 12 Paragraph (1).

\section{The Dynamics of the Kiai's Views}

An institution is categorized as pesantren if it has five significant elements, i.e. kiai (or other similar names), santri, pondok (or boarding school), mosque (or prayer house), and studies of the yellow books (classical Islamic texts). Besides, pesantren must have no objection to accept the Unitary State of the Republic of Indonesia (NKRI) based on Pancasila, UUD 1945, and Bhinneka Tunggal Ika. This requirement is clearly stated in the Regulation of the Ministry of Religious affairs Number 13, 2014, and the Decision of the Directorate General of Islamic Education Number 5839, 2014. Out of the five elements, the kiai is the most essential (Indrawati, 2014). Thus, the growth of pesantren depends on the personal ability of the kiai (Muhith, 2017).

Due to his central role, the kiai must possess an educational experience in pesantren and competence in Islam (PMA No. 13, 2014). Another pivotal element is the presence of yellow books that become the most prominent reference for the scientific tradition of Islam in pesantren (PMA Number 13, 2014 , Article 1 [3]). The yellow books can preserve the Islamic 
intellectual tradition as developed by Muslim scholars in the Middle Age (Rahman, 2017). The kiai, as a personification of Islamic tenets, transfers the values contained in the yellow books (Wahid, 2001). Both ingredients are always inherent within the daily life of the students in pesantren. The fact that pesantren has invested a total, thorough, and longlasting values makes it dinstinctive from other educational institutions while receing greater trust from the society (Wahid, 2001).

The yellow books have succesfully demonstrated the richness and the flexibility of the scientific tradition in pesantren. They accommodate different perspectives of scholars on almost every topic of discussion. Any development in the scientific tradition is only associated with a shift in the focus of attention. For example, some scholars at a certain moment put more emphasis on fiqh and, at some others, on the hadith (Bruinessen, 1995). The different perspectives have made the tradition of pesantren highly dynamic. In theory, the kiai in pesantren still refers to the opinions of the scholars in the yellow books, but in practice, he can understand the dynamics of social change (Taufiq, 2009). Sunan Kalijaga and Sunan Kudus, Java, Indonesia are the best examples how local culture is recognized and appreciated (Erzad \& Suciati, 2018), and majority of the kiais do the same way.

One of the distinctive characteristics of pesantren is that it always has its root in tradition while at the same time striving to respond positively to the needs of the society. Pesantren has two roles at once, preserving the tradition and promoting social change (Fauzi, 2012). Both roles become one of the main factors that determine the sustainability 
of pesantren up to now (Pribadi, 2013). The most popular dictum of pesantren is "preserving the good old tradition and adopting the new better one" (Azizy, 2002; Baso, 2015). Based on this foundation, social changes in pesantren are not solely determined by the structure outside or by itself. In this case, the duality always exists between the autonomous tradition of pesantren and the changing needs of the social structure outside.

The tradition of pesantren-, which always combines universality with locality, international science with local culture, and the highest possible achievement in science with a firmly rooted faith-always move dynamically within the current social changes. The tradition of pesantren has been always in a dialectical relation with the social dynamics. Despite the similarities, this institution is far from being singular (Raharadjo, 1985). Current studies by many social scientists showed that social dynamics does not only occur in one direction, rather they are mutually related (dialectical) and are very complex. The dual relations between the subjective agent and the objective social structure have formed social reality, supported by its own autonomus nature (Wahid, 2001). The autonomy of pesantren cannot be separated from the kiai's role and decision. As a leader, the kiai plays a crucial role and his presence is essential to pesantren (Lukens-Bull, 2004).

The government regulations on pesantren are an objective reality that the kiai has to face. As the main actor in charge of the management and development of his pesantren, the kiai will internalize dynamically the reality to preserve the tradition of pesantren and to meet the needs and 
dynamics of society as well. The dynamic attitude and actions are very much dependent on the conditions of the kiai's social and cultural background, such as education, family, environment, and life experience. The lively internalization will determine the subjectivity of the kiai. Furthermore, within his subjectivity the kiai will do externalization to develop the pesantren according to the dynamics of society. This is reasonable since pesantren is closely related with Islam-based local wisdom (Patriadi, Bakar, \& Hamat, 2015). The continuous externalization leads to the objective reality of education in pesantren in terms of its educational types and forms being developed. Therefore, every pesantren is undergoing a different phase of development in the face of the same regulation reference.

Besides, the objective reality in the development of pesantren will be internalized again by the kiai, depending on the socio-historical conditions. The new internalization will cause different externalization and objectification. The processes of internalization, externalization, and objectification have been dynamically performed. This is possible because of the kiai's dialectical efforts in addressing the government regulations. Therefore, the kiai will interprete the development of his institution in a dynamic way.

\section{E. The Dynamic Views of Kiai Lirboyo on the Development of Pesantren}

Pesantren Lirboyo is one of the Islamic boarding schools that still exists and grows despite of the up and down government policy. It is located in Kediri, East Java, Indonesia. The famous pesantren has a long history that can be traced before and after the Indonesian independence. 
Pesantren Lirboyo has many students and its alumni all over the archipelago are making valuable contributions in their respective societies, as illustrated in the guidebook of "Pesantren Lirboyo" (Tim Penyusun, 2010).

Pesantren Lirboyo is a traditional pesantren, if we have to use the distinction between the salaf (traditional) and khalaf (modern) category. Dhofier (1985) and Walbridge (1998) argued that there are two categories of pesantren: Pesantren Salaf and Pesantren Khalaf. Accordingly, the kiai can be also grouped into salaf and khalaf. The Kiai salaf are normally those who are well-educated in pesantren salaf (traditional, non-formal), while kiai khalaf are identical to those who studied in modern (formal) institutions.

Pesantren Lirboyo was founded in 1910 by KH. Abdul Karim (1856-1954M), the son-in-law of K. Sholeh in Banjar Melati, Kediri. It started from a bamboo-made small prayer house (surau) that KH. Abdul Karim built. It attracted many students to come and study with him. Shortly after, he built a cottage, which is now called pondok lama (the old cottage). The times flies but Pondok Pesantren Lirboyo keeps growing. At first, there was only an old cottage but then the other units followed (Pengurus Pondok Pesantren Lirboyo, 2007).

This pesantren is managed collectively by a number of kiais, who are the descendant of the founder; a board of supervisor composed of the eldest kiais is at the top management. The board, which was initiated by Kiai Mahrus Aly in 1966, is the highest institution in the pesantren and the members are responsible to determine the policies regarding the development of the pesantren. After Kiai Mahrus passed away, the board was under the leadership of Kiai Ahmad Idris Marzuki and succesively taken over by Kiai M. Anwar Manshur. 
The board of supervisor has the full authority to decide the development goals of the pesantren in general. Every unit may create its own activities and curriculum, but it should follow the central policy (the board of supervisors) and may not deviate from the directed policy (Kiai M. Anwar Manshur, 2019). The presence of the board aims to preserve the tradition of the pesantren. A special meeting with all of dzurriyyah (family) of Lirboyo is conducted (once a year) in order to monitor such development. The meeting is also intended to evaluate educational policies that may violate the guidance as outlined by the manager (Kiai Abdullah Kafabihi Mahrus, 2019).

As mentioned above, Lirboyo consists of a center and several units. The central Lirboyo still runs as a pesantren salaf wherein theyellow books are the first source of knowledge. The pesantren also provides Mu'adalah (i.e. Degree Equalization by the Government) in order to accomodate the needs of the graduates to pursue a higher level of study or to work in a formal employment (Kiai Abdullah Kafabihi Mahrus, 2019).

The pesantren units creatively develop a different learning curriculum in which the yellow books are not the only source of knowledge. Meanwhile, the students who are studying at schools under the government curriculum, either inside or outside the pesantren, should put more emphasis on the yellow books for the reason of which the activities outside the pesantren are being limited. The activities in pesantren should be prioritized over the others. Thus, the kiais and the managerial board of pesantren should be persistent, consistent, and patient (Kiai M. Anwar Manshur, 2019; Kiai Abdullah Kafabihi Mahrus, 2019). 
The pesantren units have their own characteristics as a response to the different demands of the society. Kiai Lirboyo does not directly change the character of the central pesantren just in order to accommodate the new needs; rather, they establish other units. These units still maintain the old tradition while accommodating the new one (modernity), seeking adjustment with the needs of the community and the existing regulations.

For Pesantren Lirboyo, keeping the status of salaf does not mean teaching only the yellow books and ignoring the development of the students' talents and skills. It provides opportunities for the students to be advanced in some fields. The pesantren carries out some extra activities, such as leadership and talent development in cooperation with some organizations. These activities provide the students with the skills needed to face the real life in society. Other extra activities include courses and trainings in IT, English, Arabic, journalism, and others. The students can voluntarily take part in a particular talent activity.

In addition to conducting non-formal education (salaf) through studies on yellow books in a classical or non-classical way, Pesantren Lirboyo also manages a unit of formal education from basic to college levels. It began to be more open by establishing a formal institution, Universitas Islam Tribakti (UIT) in 1966 through the idea of Kiai Mahrus Aly. The university now transforms into an institute (IAT). The presence of this higher education is an answer to the anxiety of society that the students (santris) must quit from the pesantren if they want to pursue their studies in college. Dhofir states that the graduates of pesantren who want to 
advance their knowledge in Islamic studies must migrate to cities where they can find IAIN (Dhofier, 1990). Santris who want to go to college does not need leave the pesantren because Lirboyo already has one.

In 1988, Kiai Imam Yahya Mahrus (the son of Kiai Mahrus Aly) established a pesantren unit called Pondok Pesantren (PP) HM al-Mahrusiyah. Under the supervision of this unit, some institutions such as SD, MTs., MA, and SMK al-Mahrusiyah are founded. Then in 1995, another pesantren unit named Pondok Pesantren Salafiyah Terpadu (PPST) ArRisalah was founded by Kiai M. Ma'roef Zainuddin and his wife, Nyai Aina Ainul Mardliyah. Nyai Aina was the daughter of Kiai M. Anwar Manshur and is the grandson of Kiai Mahrus Aly. This unit established elementary, junior, and senior high schools of Ar-Risalah. Furthermore, the other units hold the policy of allowing their students to attend schools outside the pesantren. They are PPHY (Pondok Pesantren Haji Ya'qub) and PPDS (Pondok Pesantren Darussalam). Some students in this unit are attending formal schools outside, such as senior high schools or college.

The management of education in Lirboyo does not go to only one central body, but is divided into several units in accordance with the characteristic of each unit. The kiai in each unit dialectically respond to the existing regulations according to its respective mission. The students and parents also have an option regarding the type of education that they want. Pesantren gives its best service in units tailored to the demands of the regulations, the students, and parents as well. If they prefer to study the yellow books only, they can go to the "central cottage". Similarly, if they want to study in 
formal schools in addition to learning the yellow books, they can choose PP HM al-Mahrusiyah, PP. Salafiyah Terpadu alRisalah, PPHY and PPDS.

It is part of the kiai's creativity to integrate the government regulations with the needs of the society and the tradition of the pesantren. The various options available enable the society to easily choose according to their needs. The pesantren can still preserve its idealism and characteristics, i.e. religious education through the classical yellow books, without necessarily leaving out its core business due to the existing regulations. On the other hand, the parents and students are also given options to suit their dreams or needs. The kiais in the pesantren move in a dialectical process with the existing regulations in order to keep their ideal vision and mission. The attitude of the kiais are in line with their knowledge about the importance of keeping the good old tradition and adopting the better new one (al-muhafadlah 'ala al-qadim al-shalih wa al-akhdzu bi al-jadid al-ashlah).

The policy related to the types of educational institutions cannot be separated from the role of Kiai Mahrus Aly (19071985 M.), the central leader in Pesantren Lirboyo at that time. Having no formal education or lessons from public schools, Kiai Mahrus possesses rich experience and broad insight. When he became the main manager in Pesantren Lirboyo with Kiai Marzuki Dahlan, (after Kiai Abdul Karim passed away in 1954), Kiai Mahrus made an outstanding achievement. Kiai Mahrus actively involved in the organization of Nahdlatul Ulama (NU), serving as the Rais (leader) of PWNU, East Java and the chief of the Center for Rabithah Ma'ahid al-Islamiyah. He was also an advisor to the regional Commander V of Brawijaya and has 
a close relationship with the military circle (Tim Penyusun, 2010). The depth of his religious knowledge, the breadth of his life experience, and his social interaction enabled Kiai Mahrus to develop Pesantren Lirboyo dynamically. The pesantren was succesful in meeting the needs of the community and following the government regulations.

The progressive policy and action of Kiai Mahrus Aly and some of his successors was the product of their social constructions. They organize and develop Pesantren Lirboyo in accordance with the needs and development of society. Their social constructions developed dynamically for they cannot escape from the social, cultural, and historical conditions. The concept of 'al-Muhafadhah 'ala al-Qadim alShalih wa al-Akhdzu bi al-Jadid al-Ashlah' as a dictum in the tradition of pesantren is embodied in the policy regarding the implementation of education in the pesantren. On the one hand, they maintain the traditional knowledge through reading yellow books. On the other hand, they address the government regulations and the diverse needs of society for development through the implementation of different types of education.

\section{F. Conclusion}

The development of education in pesantren is influenced by many aspects, two of which are the role of the kiais and the government regulation. Since the beginning of its development, the relationship between pesantren and the government have been ups and downs. In the era of the Islamic kingdom, this institution was very close to the government. During the reign of the colonial Dutch, it had to suffer 
pressures and limitations. Since the issuance of Law Number 20, 2003 on National Education System, pesantren began to be legally recognized as a part of the National Education System. Over the variety of conditions, the kiais hold a prominent role. The knowledge of the kiais influences the policy or actions in developing education in pesantren.

With their social constructions, the kiais are able to create a very effective policy. The government regulations on education of pesantren, as a social reality, are not textually accepted. The kiais always seek to address these regulations creatively and dynamically, because of which education in pesantren can always integrate the tradition with the coming modernity in order to meet the needs of society for development. The dialectic between the kiais through their knowledge and the government through its regulations will eventually result in dynamic and progressive policies. The knowledge (i.e. the kiais) and the reality (i.e. the government regulation) are always in a dialectical process of three effective moments, namely internalization, externalization, and objectification. This process relies highly on the background of the kiais in various aspects and the socio-historical conditions. The experience and the level of the kiais' understanding on Islam play an essential role in determining the dynamics of their policies. The creative views of the kiais have enabled pesantren to develop in diverse dimensions. 


\section{REFERENCES}

Arifin, A. Z. (2013). Charisma and Rationalisation in a Modernising Pesantren: Changing Values in Traditional Islamic Education in Java (Ph.D. Thesis). University of Western Sydney Australia, Sydney.

Azizy, Q. A. (2002). Memberdayakan Pesantren dan Madrasah. In I. S.M. (Ed.), Dinamika Pesantren dan Madrasah. Yogyakarta: Pustaka Pelajar.

Azra, A. (2015). Genealogy of Indonesian Islamic Education: Roles in The Modernization of Muslim Society. Heritage of Nusantara: International Journal of Religious Literature and Heritage, 4(1), 85-114. https://doi. org/10.31291/hn.v4i1.63.

Baso, A. (2015). Islam Nusantara: Ijtihad Jenius dan Ijma' Ulama Indonesia. Jakarta: Pustaka Afid.

Basri, H. H. (2014). Keragaman Orientasi Pendidikan di Pesantren. Jurnal Dialog, 37(2), 207-220.

Baum, G. (1999). Agama dalam Bayang-Bayang Relativisme. Yogyakarta: Tiara Wacana.

Berger, P. L. (1963). Invitation to Sociology: A Humanistic Perspective. Middlesex: Penguin Books.

Berger, P. L., \& Luckmann, T. (1966). The Social Construction of Reality: A Treatise in the Sociology of Knowledge. Middlesex: Penguin Books.

Bruinessen, M. V. (1995). Kitab Kuning Pesantren dan Tarekat. Bandung: Mizan.

Burhanudin, J. (2004). Islam dan Negara Bangsa: Melacak Akar-Akar Nasionalisme Indonesia. Studia Islamika, 11(1), 23-62. https://doi.org/10.15408/sdi.v11i1.656. 
Burhanudin, J. (2012). Ulama dan Kekuasaan: Pergumulan Elite Muslim dalam Sejarah Indonesia. Bandung: Mizan.

Dhofier, Zamakhsari. (1985). Tradisi Pesantren: Studi tentang Pandangan Hidup Kyai. Jakarta: LP3ES.

Dhofier, Zamakhsari. (2011). Tradisi Pesantren: Studi Pandangan Hidup Kyai dan Visinya Mengenai Masa Depan Indonesia. Jakarta: LP3ES.

Dhofier, Zamakhsyari. (1990). Traditional Islamic Education in the Malay Archipelago: Its Contribution to the Integration of the Malay World. Indonesia Circle. School of Oriental \& African Studies, 19(53), 19-34. https://doi. org/10.1080/03062849008729746

Dirdjosanjoto, P. (1999). Memelihara Umat: Kyai Pesantren Kyai Langgar. Yogyakarta: LKiS.

Erzad, A. M., \& Suciati, S. (2018). The Existence of Kudus Islamic Local Culture to Prevent Radicalism in Globalization Era. QIJIS (Qudus International Journal of Islamic Studies), 6(1), 39-56.

Fauzi, M. L. (2012). Traditional Islam in Javanese Society: The Roles of Kyai and Pesantren in Preserving Tradition and Negotiating Modernity. Journal of Indonesian Islam, 6(1), 125-144. https://doi.org/10.15642/JIIS.2012.6.1.125144

Frederick, W. H., \& Worden, R. L. (2011). Indonesia: A Country Study. New York: Library of Congres. Federal Research Division.

Furnivall, J. S. (2010). Netherlands India: A Study of Plural Economy. New York: Cambridge University Press.

Goksoy, I. H. (2002). The Policy of The Dutch Government Towards Islam in Indonesia. Studia Islamika: Indonesian Journal for Islamic Studies, 19(1). 
Indrawati, N. K. (2014). Management by Inspiration: Implementation of Transformational Leadership on Business at Pondok Pesantren Sunan Drajat. Procedia Social and Behavioral Sciences, 115, 79-90.

Jabali, F., \& Jamhari, J. (2003). The Modernization of Islam in Indonesia: An Impact Study on the Cooperation between the IAIN and McGill University. Montreal: IndonesiaCanada Islamic Higher Education Project.

Kiai M. Anwar Manshur. (2019). Pengasuh dan Ketua Majelis Pembina Pondok Pesantren Lirboyo, Kediri, Jawa Timur.

Kiai Abdullah Kafabihi Mahrus. (2019). Pengasuh Pondok Pesantren Lirboyo Kediri, Jawa Timur.

Laffan, M. F. (2003). Islamic Nationhood and Colonial Indonesia: The Umma below the Wind. London: Routledge.

Latif, Y. (2005). Inteligensia Muslim dan Kuasa: Genealogi Inteligensia Muslim Indonesia Abad ke-20. Bandung: Mizan.

Lukens-Bull, R. A. (2004). Jihad ala Pesantren di Mata Antropolog Amerika. Yogyakarta: Gama Media.

Mannheim, K. (1954). Ideology and Utopia: An Introduction to the Sociology of Knowledge. London: Routledge.

Muhajir, M. (2010). Pergeseran Kurikulum Madrasah Dalam Undang-Undang Sistem Pendidikan Nasional (Ph.D. Thesis). UIN Syarif Hidayatullah, Jakarta.

Muhith, Abd. (2017). Kiai's Transformational Leadership in Establishing Organisational Culture at Gender Pesantren. Global Journal of Arts, Humanities and Social Sciences, 6(1).

OECD/ADB. (2015). Education in Indonesia: Rising to the Challenge. Paris: OECD Publishing. 
Patriadi, H. B., Bakar, Mohd. Z. A., \& Hamat, Z. (2015). Human Security in Local Wisdom Perspective: Pesantren and its Responsibility to Protect People. Procedia Environmental Sciences, 28, 100-105. https://doi. org/10.1016/j.proenv.2015.07.015

Pengurus Pondok Pesantren Lirboyo. (2007). Profil Singkat Pondok Pesantren Lirboyo.

Peraturan Menteri Agama Republik Indonesia Nomor 13 Tahun 2014. , (2014).

Peraturan Menteri Agama Republik Indonesia Nomor 18 Tahun 2014. , (2014).

Peraturan Menteri Agama Republik Indonesia Nomor 71 Tahun 2015. , (2015).

Peraturan Pemerintah Nomor 55 Tahun 2007. , (2007).

Pramono, D. (2018). The Authority of Kyai Toward The Santri: A Review of Gender Construction at PondokPesantren. Komunitas: International Journal of Indonesian Society and Culture, 10(1).

Pribadi, Y. (2013). Religious Networks in Madura: Pesantren, Nahdlatul Ulama and Kiai as the Core of Santri Culture. Al-Jami'ah: Journal of Islamic Studies, 51(1).

Raharadjo,D.(1985). Pergulatan Dunia Pesantren:Membangun dari Bawah. Jakarta: LP3ES.

Rahman, Y. (2017). Feminist Kyai: KH. Husein Muhammad the Feminist Interpretation on Gendered Verses and the Qur'ān-Based Activism. Al-Jāmi'ah, 55(2).

Raihani, R. (2012). Report on Multicultural Education in Pesantren. Compare, 42(4).

Samuel, H. (2012). Peter Berger: Sebuah Pengantar Ringkas. Depok: Kepik. 
Shiozaki, Y., \& Kushimoto, H. (2014). Reconfigurations of Islamic authority in Malaysia. Asian Journal of Social Science, 42(5), 602-619.

Sidel, J. T. (2001). It Takes a Madrasah?: Habermas Meets Bourdieu in Indonesia. South East Asia Research, 9(1), 109-122.

Suhartini, Rr. (2013). When Religion Goes to the Workplace: The Sociology of Knowledge about Religiosity. Journal of Indonesian Islam, 7(2).

Suharto, T. (2013). Pendidikan Berbasis Masyarakat Organik: Pengalaman Pesantren Persatuan Islam. Surakarta: Fataba Press.

Suharto, T. (2014). Bayn Ma'had Tubuireng wa Madrasat Manba' al-'Ulum: Dirasah Tarikhiyah 'an nash'at mafhum 'al-Madrasah fi al-Ma'had.' Studia Islamika: Indonesian Journal for Islamic Studies, 21(1).

Suparta, H. M. (2014). Masa Depan Pesantren Pasca UU 20/2003 Tentang Sistem Pendidikan nasional. Analisis: Jurnal Studi Keislaman, 14(1).

Taufiq, A. (2009). PerspektifGender Kyai Pesantren: Memahami Teks Menurut Konteks Relasi Gender dalam Keluarga. Kediri: STAIN Kediri Press.

Tim Penyusun. (2010). Pesantren Lirboyo: Sejarah, Peristiwa, Fenomena dan Legenda. Kediri: Lirboyo Press.

Tolchah, Moch. (2014). The Political Dimension of Indonesian Islamic Education in The Post-1998 Reform Period. Journal of Indonesian Islam, 8(2).

Turmudzi, E. (2006). Struggling For the Umma: Changing Leadership Roles of Kyai in Jombang East Java. Australia: ANU e-Press. 
Ubaidillah, U. (2014). The Role of Kyai in Contentious Politics Concerning Land Dispute in Urutsewu Kebumen. QIJIS: Qudus Internationel Journal of Islamic Studies, 2(1), 6381.

Undang-Undang Nomor 20 tahun 2003. , (2003).

Wahid, A. (2001). Menggerakkan Tradisi. Yogyakarta: LKiS.

Walbridge, L. S. (1998). The "Santri-Wati" of Indonesia's "Pesantren": Orientations of Students of Three girls' Religious Schools. Islamic Studies, 37(4).

Yamaguchi, M. (2016). Islamic School and Arab Association: Ahmad Surkati's Reformist Thought and Its Influence on the Educational Activities of al-Irsyad. Studia Islamika: Indonesian Journal for Islamic Studies, 23(3).

Yusuf, Moh. A. (2010). Integrasi Sistem Pengkajian Akidah di Pondok Pesantren dan Perguruan Tinggi Agama Islam. Empirisma, 19(2).

Zuhri, M. (2006). Political and Social Influences on Religious School: A Historical Perspective on Indonesian Islamic School Curricula (Ph.D. Thesis). McGill University, Montreal.

Zulkarnain, F. (2015). The Thought of KH. Imam Zarkasyi on Multicultural Education at Modern Islamic Boarding School Gontor Ponorogo. Jurnal Pendidikan Islam, 2(1). 